


\section{HELLENISTIC GULTURE AND SOGIETY}

General Editors: Anthony W. Bulloch, Erich S. Gruen, A. A. Long, and Andrew F. Stewart

I. Alexander to Actium: The Historical Evolution of the Hellenistic Age, by Peter Green

II. Hellenism in the East: The Interaction of Greek and Non-Greek Civilizations from Syria to Central Asia after Alexander, edited by Amélie Kuhrt and Susan Sherwin-White

III. The Question of "Eclecticism": Studies in Later Greek Philosophy, edited by $7 . M$. Dillon and $A$. A. Long

IV. Antigonus the One-Eyed and the Creation of the Hellenistic State, by Richard A. Billows

V. A History of Macedonia, by R. Malcolm Errington, translated by Catherine Errington

VI. Attic Letter-Cutters of 229 to 86 B.c., by Stephen V. Tracy

VII. The Vanished Library: A Wonder of the Ancient World, by Luciano Canfora

VIII. Hellenistic Philosophy of Mind, by Julia Annas

IX. Hellenistic Culture and History, edited by Peter Green

X. The Best of the Argonauts: The Redefinition of the Epic Hero in Book 1 of Apollonius's Argonautica, by James 7. Clauss

XI. Faces of Power: Alexander's Image and Hellenistic Politics, by Andrew Stewart

XII. Images and Ideologies: Self-Definition in the Hellenistic World, edited by $A$. W. Bulloch, E. S. Gruen, A. A. Long, and A. Stewart

XIII. From Samarkand to Sardis: A New Approach to the Seleucid Empire, by Susan Sherwin-White and Amélie Kuhrt

XIV. Regionalism and Change in the Economy of Independent Delos, 314-167 B.C., by Gary Reger

XV. Hegemony to Empire: The Development of the Roman Imperium in the East from 148 to 62 B.c., by Robert Kallet-Marx

XVI. Moral Vision in the Histories of Polybius, by Arthur M. Eckstein

XVII. The Hellenistic Settlements in Europe, the Islands, and Asia Minor, by Getzel M. Cohen

XVIII. Interstate Arbitrations in the Greek World, 337-90 B.c., by Sheila L. Ager

XIX. Theocritus's Urban Mimes: Mobility, Gender, and Patronage, by Joan B. Burton

XX. Athenian Democracy in Transition: Attic Letter-Cutters of 340 to 290 B.C., by Stephen V. Tracy 
XXI. Pseudo-Hecataeus, On the Jews: Legitimizing the Jewish Diaspora, by Bezalel Bar-Kochva

XXII. Asylia: Territorial Inviolability in the Hellenistic World, by Kent 7 . Rigsby

XXIII. The Cynics: The Cynic Movement in Antiquity and Its Legacy, edited by $R$. Bracht Branham and Marie-Odile Goulet-Cazé

XXIV. The Politics of Plunder: Aitolians and Their Koinon in the Early Hellenistic Era, 279-217 B.C., by Joseph B. Scholten

XXV. The Argonautika, by Apollonios Rhodios, translated, with introduction, commentary, and glossary by Peter Green

XXVI. Hellenistic Constructs: Essays in Culture, History, and Historiography, edited by Paul Cartledge, Peter Garnsey, and Erich Gruen

XXVII. Josephus' Interpretation of the Bible, by Louis H. Feldman

XXVIII. Poetic Garlands: Hellenistic Epigrams in Context, by Kathryn $\mathcal{7}$. Gutzwiller

XXIX. Religion in Hellenistic Athens, by fon D. Mikalson

XXX. Heritage and Hellenism: The Reinvention of Jewish Tradition, by Erich $S$. Gruen 



\section{Heritage and Hellenism}


THE S. MARK TAPER FOUNDATION IMPRINT IN JEWISH STUDIES

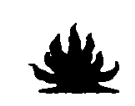

BY THIS ENDOWMENT

THE S. MARK TAPER FOUNDATION SUPPORTS

THE APPRECIATION AND UNDERSTANDING

OF THE RIGHNESS AND DIVERSITY OF

JEWISH LIFE AND CULTURE 


\title{
Heritage and Hellenism
}

The Reinvention of Jewish Tradition

\author{
Erich S. Gruen
}




\title{
The publisher gratefully acknowledges the contribution toward the publication \\ of this book provided by the S. Mark Taper Foundation
}

\author{
University of California Press \\ Berkeley and Los Angeles, California \\ University of California Press, Ltd. \\ London, England \\ First paperback printing 2002 \\ (C) 1998 by \\ The Regents of the University of California
}

Library of Congress Cataloging-in-Publication Data

\section{Gruen, Erich S.}

Heritage and hellenism : the reinvention of Jewish tradition / Erich S. Gruen.

p. $\quad$ cm. - (Hellenistic culture and society ; $3^{\circ}$ )

Includes bibliographical references and index.

ISBN o-520-23506- I (pbk. : alk. paper)

1. Judaism-History-Post-exilic period, 586 B.C.-2 10 A.D.

2. Greek literature-Jewish authors-History and criticism.

3. Judaism-Apologetic works-History and criticism. 4. Hellenism.

I. Title. II. Series.

$\mathrm{BM}_{176 . \mathrm{G}_{7} 8 \quad 1998}$

$29^{\prime} .09^{\prime} 014-$ dc2

$97-38808$

CIP

Printed in the United States of America

$\begin{array}{ccccccccc}09 & 08 & 07 & 06 & 05 & 04 & 03 & 02 \\ 9 & 8 & 7 & 6 & 5 & 4 & 3 & 2 & 1\end{array}$

The paper used in this publication meets the minimum requirements of ANSI/ NISO Z $39 \cdot 4^{8-1992}$ (R 1997) (Permanence of Paper). () 
Manibus matris 
